\title{
Sectoral regimes, productivity and international competitiveness
}

\section{Jorge Katz}

Director, Division of

Production, Productivity

and Management, ECLAC

jkatz@eclac.cl

\section{Giovanni Stumpo}

Joint ECLAC/UNIDO

Industrial and Technological

Development Unit, ECLAC

gstumpo@eclac.cl
This article seeks to analyse some mesoeconomic and microeconomic aspects related with productivity and international competitiveness in the context of the new Latin American economic model. These aspects go a long way towards explaining why those variables have not evolved satisfactorily in the different countries and sectors of activity, and why a strictly macroeconomic reading prevents a proper understanding of the changes which are taking place in society at the economic, technological and institutional levels, as well as impeding the identification of a public policy agenda which could help improve the implications of the process of change which is under way.

Within this process, new patterns of micro-economic behaviour have been taking shape in which imported capital goods and intermediate imputs have been displacing locally produced goods and the local technological efforts associated with their production. This has been giving rise to a new production organization model which is more closely linked with external sources of growth than in the past. 
I

\section{Introduction}

In line with the principle of "appreciative theorizing" (Nelson, 1997), in several recent studies ECLAC has described various stylized features of the new model of social and production organization that has been taking shape in the countries of Latin America and the Caribbean after the structural reforms of the 1990s which were designed to improve competitiveness. ${ }^{1}$

It is noted in these studies that the transition from a paradigm of inward-looking development led by the State to another, more open and deregulated, paradigm -in which the "hidden hand"takes on a leading role and guides resource allocation- has been giving rise in the various countries of the region to the development of new patterns of production specialization and insertion in the world markets for goods and services. This has taken place in the context of a prolonged episode of Schumpeterian "creative destruction" in which one model of production organization and institutional and technological behaviour has been gradually displaced by another, through the joint and interdependent action of economic, technological and institutional forces. The interdependence of macroeconomic and microeconomic factors clearly occupies a central place in this situation. The macro economy -uncertain and subject to cyclical fluctuations largely due to the erratic behaviour of international capital markets- induces defensive forms of microeconomic behaviour which, in turn, feed the climate of feeble global dynamism, with improvements in productivity and international competitiveness which are lower than those registered in other parts of the world. This is what prevents the countries of the region from closing the relative productivity and income gap that separates them from the industrialized world. In a macro economy that is unable to overcome its high degree of uncertainty and risk, improvements in productivity at the microeconomic level are achieved more through the dismissal of workers from relatively "old" plants than through major programmes of investment and technological modernization. Strictly economic variables -such as the exchange rate, interest

${ }^{1}$ Stallings and Peres (2000), World Development (2000), Katz (2000), Moguillansky and Bielschowsky (2000), Weller (2000), Ffrench-Davis (1999) and Ocampo (2001). rates, investment and real wages- interact with others of an institutional and technological nature -such as property rights, the greater or lesser degree of imperfection of factor markets, or the level of technological capability attained by the different countries- to give rise to a long-term growth process which is far from satisfactory.

The ECLAC studies also show that, in addition to being unsatisfactory in terms of growth rates and microeconomic efficiency, the new Latin American economic model does not exhibit any great achievement in terms of equity either. Indeed, it is characterized by profound structural heterogeneity which is in many respects more marked than during the years of import substitution industrialization. Some economic activities, regions, or even individual economic agents within each production sector have managed to adapt better -through imperfect access to factor markets, asymmetries of information or greater political lobbying power- to the new rules of the game, but others have not been able to do so. The former have cashed in on the new opportunities opened up by the change in the global system of incentives prevailing in society, whereas the situation of the latter has tended to deteriorate with time, and they have lost relative participation in the production structure or have even disappeared from it altogether. The process of structural change which is under way is also marked by a sharp increase in the degree of economic concentration and the consolidation of new monopoly positions in the production apparatus, within a context where the State has lost regulatory power and the capacity to intervene.

The present article aims to analyse various macroeconomic and microeconomic aspects relating to productivity and international competitiveness. We will argue that both these aspects play an important -and often forgotten- role in explaining why the latter variables have not evolved satisfactorily in the different countries and sectors of activity and why a strictly macroeconomic reading inhibits our capacity to understand the changes taking place in society at the production, technological and institutional levels, as well as preventing the identification of a public policy agenda which could help improve the implications of the transformation under way. If the diagnosis is

SECTORAL REGIMES, PRODUCTIVITY AND INTERNATIONAL COMPETITIVENESS • JORGE KATZ AND GIOVANNI STUMPO 
exclusively macroeconomic, we can hardly be surprised that the dominant agenda limits itself to recommending "more of the same": i.e., further increasing trade openness, continuing to deregulate markets, and finishing off the privatization of everything which has not yet been privatized.

This article consists of four sections. After this introduction, section II compares the global performance of the region during the inward-looking growth stage (1940-1980) with the performance of the 1990s, when the Latin American countries opted for a growth strategy more open to outside competition, more deregulated and with less State participation in production activities. The overall regional pattern, however, does not describe the different national cases accurately, so after presenting the global panorama we move on to analyse the differences in performance between individual countries and production activities, focusing in particular on indicators of labour productivity and revealed international competitiveness.

In section III we make a tentative simple effort at appreciative theorization on this process. Our reading of it is based on the Schumpeterian notion of "creative destruction". We argue that sectoral technological and competitive regimes change through the "death" and "birth" of firms, through the arrival of new international actors, and through the aggiornamento of each production sector's institutions, ${ }^{2}$ technologies, and rules of behaviour. We are in the presence of a process of long-term structural transformation which economists are still far from fully understanding. Finally, section IV presents some concluding remarks on the processes analysed.

\section{II}

\section{The present situation}

\section{The overall picture}

The numbers in table 1 explain the great scepticism currently prevailing about the effects of the reforms of the 1990s. The information is condensed into four specific dimensions: i) the behaviour of the macro economy, reflected in the rate of inflation of the region as a whole; ii) the performance of the external sector, summed up by the aggregate growth rates of imports and exports; iii) the functioning of the production structure, represented by the growth rates of the gross domestic product and labour productivity, and iv) equity, represented by an index of poor households as a proportion of total population.

The pattern of successes and failures is obvious. The region has made a lot of progress in handling macroeconomic policy. The rate of inflation, indicates that the performance of the Latin American economies improved considerably in the 1990s. The Latin American countries were also more open to trade than in previous decades. The growth rate of imports was higher than that of exports, however, suggesting that the region's openness to trade was greater for imports than for exports. This suggests a certain degree of vulnerability in the external sector of the new Latin
American economic model, to which the governments of the region are now paying increasing attention. ${ }^{3} \mathrm{We}$ will return to this subject later in this article. At the same time, however, we must also bear in mind that the averages shown in the table are strongly influenced by Mexico, which managed to double total exports in the 1990s thanks to the rapid expansion of its in-bond

\footnotetext{
${ }^{2}$ The term "institutions" is used by economists rather ambiguously to refer both to agencies or entities -banks, universities, customs systems- and to norms of conduct or rules of behaviour. Thus, the patents system is an "institution", as also is tariff protection. With regard to this debate, see David (1994).

${ }^{3}$ In a recent study on Brazilian exports, Miranda (2000) argues that it is not only urgent to increase exports but will probably also be urgent in the future to begin to substitute imports once again in sectors of production which make intensive use of imported intermediate inputs -such as capital goods, electronic products or pharmaceutical raw materials- and which are largely responsible for the big external trade deficits currently registered by a number of economies of the region. A similar debate is currently under way in Argentina. In many respects this recalls the old ECLAC debates of the 1950 on the chronic external constraints affecting many Latin American economies. We will return to this subject later in this article (see Miranda, 2000).
} 
TABLE 1

Global performance of Latin America during the import substitution industrialization period and the 1990s

(Percentages)

\begin{tabular}{|c|c|c|c|c|}
\hline & 1945-1980 & $1980-1990$ & $1990-2000$ & 2000 \\
\hline Annual rate of inflation & 20 & 400 & 170.0 & 9.2 \\
\hline Growth rate of exports & 2.1 & 4.4 & 9.4 & 11.1 \\
\hline Growth rate of imports & 5.9 & -0.8 & 12.8 & 12.3 \\
\hline Growth rate of GDP & 5.6 & 1.2 & 3.3 & 4.3 \\
\hline Growth rate of per capita GDP & 3.1 & -1.8 & 1.6 & 2.2 \\
\hline Percentage of poor households & 35 & 41 & 38 & 38 \\
\hline
\end{tabular}

Source: ECLAC, 2000.

assembly industry, which supplies the United States market with television sets, video recorders, computers and vehicles. ${ }^{4}$

The growth and equity performance of the region, however, seems less satisfactory if we look at the indicators for production, labour productivity and percentage of "poor" households in total population, which do not on the whole display any long-term improvement, except in comparison with the "lost decade" of the 1980s.

\section{Differences between countries}

There are very few countries in the region which grew faster during the 1990s than in their import substitution industrialization stage and which improved on their historical GDP growth rate. In fact, only Chile, Argentina, Bolivia and Uruguay did so (figure 1). In all the other countries their performance in the 1990s was clearly worse, especially in the case of the two largest economies of the region -Brazil and Mexicowhich only recovered a higher growth rate towards the end of the decade, although such growth rate was still below that of the 1970 s.

A similar pattern -big differences between the performance of individual countries- is seen when we

\footnotetext{
${ }^{4}$ Within only a few years Mexico has risen from US\$ 60 billion of exports to over US\$ 150 billion; a little less than half of this figure corresponds to in-bond assembly production for the United States market. This situation has currently given rise to a far-reaching debate among analysts of the Mexican model on the amount of local added value and the development of local engineering capacity attributable to the growth of the in-bond assembly industry (see Buitelaar, Padilla and Urrutia, 1999; Gerber, 2000; Dussel, 2000a; Cimoli, 2001).
}

FIGURE 1

Latin America: Average growth of gross domestic product, 1991-2000

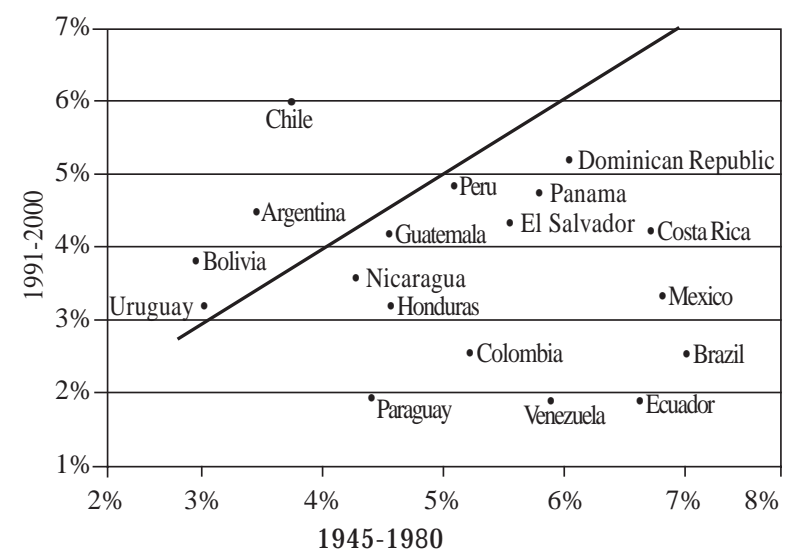

Source: ECLAC, 2000.

compare the indicators of revealed international competitiveness.

The aggregate information shows that the region as a whole has not significantly improved in terms of penetration of world markets. Thus, Latin America generated $5.57 \%$ of total world trade in 1985, and this figure had only risen to $5.67 \%$ by 1998 . Even so, a few countries did manage to gain relatively larger shares of world trade flows during the period in question. This was especially so in the case of Mexico, whose share of total world imports rose from $1.55 \%$ to $2.24 \%$ between those years. To a much smaller extent, this was also the case of Argentina and Chile, which rose respectively from $0.37 \%$ and $0.23 \%$ of world imports in 1985 to $0.51 \%$ and $0.32 \%$ in 1998 . Marginal increases were registered by Costa Rica, El Salvador, Guatemala, Honduras and the Dominican Republic, whose shares grew much less (table 2). 
TABLE 2

Latin America and the Caribbean:

Market share in world imports, 1985-1998

\begin{tabular}{|c|c|c|c|}
\hline \multirow[t]{2}{*}{ Country } & \multicolumn{3}{|c|}{ Market share } \\
\hline & 1985 & 1998 & Difference \\
\hline Argentina & 0.37 & 0.51 & 0.14 \\
\hline Chile & 0.23 & 0.32 & 0.09 \\
\hline Mexico & 1.55 & 2.24 & 0.69 \\
\hline Costa Rica & 0.07 & 0.10 & 0.03 \\
\hline El Salvador & 0.04 & 0.05 & 0.01 \\
\hline Guatemala & 0.06 & 0.08 & 0.02 \\
\hline Honduras & 0.05 & 0.07 & 0.02 \\
\hline Dominican Republic & 0.08 & 0.10 & 0.02 \\
\hline Bolivia & 0.04 & 0.02 & -0.02 \\
\hline Brazil & 1.37 & 1.01 & -0.36 \\
\hline Colombia & 0.24 & 0.24 & 0.00 \\
\hline Ecuador & 0.17 & 0.11 & -0.06 \\
\hline Paraguay & 0.03 & 0.03 & 0.00 \\
\hline Peru & 0.17 & 0.12 & -0.05 \\
\hline Uruguay & 0.07 & 0.06 & -0.01 \\
\hline Venezuela & 0.66 & 0.41 & -0.25 \\
\hline Nicaragua & 0.02 & 0.02 & 0.00 \\
\hline Barbados & 0.02 & 0.00 & -0.02 \\
\hline Cuba & 0.03 & 0.02 & -0.01 \\
\hline Haiti & 0.03 & 0.01 & -0.02 \\
\hline Jamaica & 0.04 & 0.04 & 0.00 \\
\hline Trinidad and Tobago & 0.10 & 0.04 & -0.06 \\
\hline Guyana & 0.02 & 0.01 & -0.01 \\
\hline Panama & 0.10 & 0.05 & -0.05 \\
\hline Suriname & 0.02 & 0.01 & -0.01 \\
\hline
\end{tabular}

Source: CAN 2000 (Competitive analysis of nations, 2000 version): a computer programme prepared by the Industrial and Technological Development Unit, Division of Production, Productivity and Management, ECLAC.

In other words, regardless of whether we look at output and labour productivity statistics or at trade indicators which reflect revealed competitiveness, it is clear that at the aggregate level Latin America registered little improvement in the 1990s. Only a few countries of the region managed to improve on their previous performance. Furthermore, the two sets of data show that there is not always a good level of correlation between the two indicators. In the case of Mexico, for example, the success obtained in the field of revealed competitiveness contrasts sharply with its unsatisfactory showing in terms of labour productivity (figure 2). Export-led growth does not always seem to be as automatic as is often assumed in current debates on growth.
FIGURE 2

Latin America: Labour productivity, 1951-1980

(Average growth of gross domestic product per active worker)

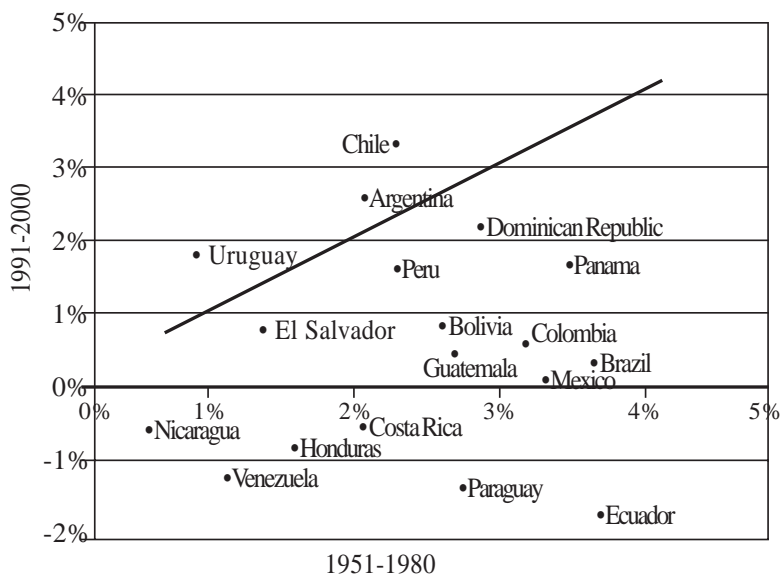

Source: ECLAC, 2000.

\section{Sectoral patterns of production specialization and world trade insertion: sectoral catching-up and lagging behind}

Production and productivity statistics on the one hand and international trade figures on the other enable us to continue to progress in analysing and describing the restructuring of the production apparatus after the recent structural reforms. Our indicators clearly show that in the 1990s two main dominant production and trade specialization models became established in Latin America.

The first of these models is characteristic of the Southern Cone countries (Chile, Argentina, Brazil) and some Andean countries (Colombia and Peru), and shows a clear leaning towards activities that involve the processing of natural resources to produce industrial commodities such as vegetable oils, pulp and paper, iron and steel, fish meal, etc. From the point of view of the organization of production, these are industries that make intensive use of natural resources and produce goods in highly automated plants, using a great deal of capital and little labour. From the point of view of international trade, they are production sectors where world demand grows slowly and price- and incomeelasticity are low. Finally, from the technological angle they may be described as mature industries where there are no great engineering efforts in the design of new products, although efforts are made to improve production processes and the organization of production (especially as regards transport, refrigeration, port operations, packaging, etc.). 
The case of Mexico and a number of the smaller Central American countries is different. Here, the pattern of production specialization has gradually been moving towards greater relative participation of the assembly of electronic equipment, computers and clothing, mainly for the United States market. Some of these industries have operated under the maquila system, based almost entirely on imported intermediate inputs (Dussel, 2000b; Buitelaar, 1999). All of them make intensive use of unskilled labour. The Mexican assembly industry generated over a million new jobs in the 1990s. Using "state of the art" technology and sophisticated just-in-time supply logistics for parts and components, as well as total quality techniques brought over almost integrally from the respective parent firms, ${ }^{5}$ but paying wages which are only a fraction - not much than $10 \%$ - of those paid by developed countries, those assembly plants exclusively cater for the United States domestic market. Demand on that market grew very rapidly in the 1990s, and both product design (which is not done in the region) and brand names play an important role in a context of imperfectly competitive markets.

Table 3 shows that the relative weight of resourceprocessing industries and foodstuffs grew significantly in Argentina, Chile, Colombia and Peru between 1970

TABLE 3

Latin America (six countries): Structure of industrial added value ${ }^{a}$

(Percentage composition)

\begin{tabular}{|c|c|c|c|c|c|c|c|c|c|c|c|c|}
\hline \multirow[b]{2}{*}{ Sectors ${ }^{\mathrm{b}}$} & \multicolumn{4}{|c|}{ Argentina } & \multicolumn{4}{|c|}{ Brazil } & \multicolumn{4}{|c|}{ Mexico } \\
\hline & 1970 & 1980 & 1990 & 1999 & 1970 & 1980 & 1990 & 1999 & 1970 & 1980 & 1990 & 1999 \\
\hline 01 & 13.2 & 13.4 & 8.8 & 10.8 & 16.2 & 25.0 & 22.0 & 24.0 & 12.0 & 14.9 & 13.7 & 15.7 \\
\hline 02 & 10.9 & 13.1 & 6.4 & 9.9 & 6.8 & 8.7 & 7.6 & 7.6 & 8.4 & 12.4 & 12.9 & 16.4 \\
\hline 03 & 24.1 & 26.5 & 15.3 & 20.6 & 23.0 & 33.7 & 29.6 & 31.6 & 20.5 & 27.3 & 26.7 & 32.1 \\
\hline 04 & 33.5 & 32.5 & 40.6 & 38.3 & 14.5 & 13.1 & 16.1 & 17.4 & 26.1 & 21.8 & 22.7 & 22.0 \\
\hline 05 & 18.3 & 20.8 & 24.0 & 20.2 & 29.2 & 26.7 & 26.1 & 27.4 & 23.3 & 24.9 & 25.5 & 23.2 \\
\hline 06 & 51.8 & 53.4 & 64.6 & 58.5 & 43.7 & 39.9 & 42.2 & 44.9 & 49.4 & 46.7 & 48.2 & 45.1 \\
\hline 07 & 24.0 & 20.1 & 20.2 & 20.9 & 33.4 & 26.4 & 28.2 & 23.5 & 30.2 & 26.0 & 25.1 & 22.8 \\
\hline \multirow[t]{2}{*}{08} & 100.0 & 100.0 & 100.0 & 100.0 & 100.0 & 100.0 & 100.0 & 100.0 & 100.0 & 100.0 & 100.0 & 100.0 \\
\hline & \multicolumn{4}{|c|}{ Chile } & \multicolumn{4}{|c|}{ Colombia } & \multicolumn{4}{|c|}{ Peru } \\
\hline Sectors $^{b}$ & 1970 & 1980 & 1990 & 1999 & 1970 & 1980 & 1990 & 1999 & 1970 & 1980 & 1990 & 1999 \\
\hline 01 & 15.9 & 10.4 & 10.8 & 11.9 & 12.3 & 11.1 & 9.7 & 9.7 & 5.7 & 9.9 & 6.2 & 4.7 \\
\hline 02 & 7.7 & 3.4 & 2.3 & 1.9 & 3.0 & 4.2 & 3.6 & 6.3 & 6.5 & 8.6 & 5.3 & 0.9 \\
\hline 03 & 23.6 & 13.8 & 13.1 & 13.8 & 15.3 & 15.3 & 13.2 & 16.0 & 12.1 & 18.5 & 11.5 & 5.6 \\
\hline 04 & 24.4 & 33.9 & 33.5 & 36.2 & 31.3 & 32.7 & 32.6 & 33.1 & 34.1 & 25.6 & 31.7 & 26.8 \\
\hline 05 & 21.0 & 23.7 & 25.8 & 24.9 & 18.9 & 20.1 & 24.1 & 22.3 & 19.4 & 25.0 & 26.0 & 31.1 \\
\hline 06 & 45.4 & 57.5 & 59.4 & 61.2 & 50.2 & 52.7 & 56.7 & 55.3 & 53.5 & 50.7 & 57.7 & 57.8 \\
\hline 07 & 31.0 & 28.7 & 27.5 & 25.0 & 34.5 & 32.0 & 30.1 & 28.7 & 34.4 & 30.8 & 30.8 & 36.6 \\
\hline 08 & 100.0 & 100.0 & 100.0 & 100.0 & 100.0 & 100.0 & 100.0 & 100.0 & 100.0 & 100.0 & 100.0 & 100.0 \\
\hline
\end{tabular}

Source: PADI (Industrial Dynamics Analysis Programme): a computer programme prepared by the Industrial and Technological Development Unit, Division of Production, Productivity and Management, ECLAC.

a In all cases the petroleum refining sector (ISIC 353) has been excluded. In the case of Chile, industrial production of copper (ISIC 372) has also been excluded.

b The corresponding sectors are:

01 Sectors making intensive use of engineering services, except the motor industry (ISIC $381,382,383,385$ ).

02 Motor industry (ISIC 384).

03 Total for sectors making intensive use of engineering services $(01+02)$.

${ }^{5}$ On recent visits to plants in the Tijuana area it was noted that, while some assembly firms have in-plant engineering groups or departments for making process or organizational improvements, others -including nearby competitors- do not have them. This
04 Foodstuffs, beverages and tobacco (ISIC 311, 313, 314).

05 Other sectors making intensive use of natural resources (ISIC $331,341,351,354,355,362,369,371,372$ ).

06 Total for sectors making intensive use of natural resources $(04+05)$.

07 Sectors making intensive use of labour (ISIC 321, 322, 323, $324,332,342,352,356,361,390)$.

08 Total for manufacturing.

obviously affects the comparative competitiveness of the firms. Sanyo and Samsung, for example, have very different strategies in this respect, although they are long-standing competitors in the United States television market. 
and the end of the 1990s, and in Brazil during the 1980s and 1990s. The table also shows, however, that this was not the case in Mexico. The motor industry was a "winner" during the 1990s in Argentina and Brazil, ${ }^{6}$ and from the 1970s on in Mexico. Industries producing wage goods such as footwear, textiles and furniture lost relative ground. That was also the case -particularly in
Argentina and even more so in Chile and Peru- with industries producing capital goods, agricultural equipment and other engineering-intensive activities.

Complementing the foregoing, but this time from the point of view of trade statistics, tables 4 and 5 show the different patterns of production and trade specialization established by Mexico and Argentina

TABLE 4

Mexico: Aspects of its international competitiveness in world imports, 1985-1998

I. Market share

Natural resources ${ }^{\mathrm{a}}$

Manufactures based on natural resources ${ }^{b}$

Manufactures not based on natural resources ${ }^{c}$

- Low technology ${ }^{\mathrm{d}}$

- Medium technology

- High technology $\mathrm{f}^{\mathrm{f}}$

Others ${ }^{g}$

II. Structure of exports

Natural resources ${ }^{\mathrm{a}}$

Manufactures based on natural resources ${ }^{b}$

Manufactures not based on natural resources ${ }^{c}$

- Low technology ${ }^{\mathrm{d}}$

- Medium technologye

- High technology

Others ${ }^{\mathrm{g}}$

\begin{tabular}{|c|c|c|c|}
\hline 1985 & 1990 & 1995 & 1998 \\
\hline 1.55 & 1.29 & 1.73 & 2.24 \\
\hline 3.59 & 2.38 & 2.05 & 2.26 \\
\hline 0.82 & 0.67 & 0.79 & 0.96 \\
\hline 0.96 & 1.18 & 1.89 & 2.53 \\
\hline 0.59 & 0.82 & 1.41 & 2.12 \\
\hline 0.98 & 1.33 & 2.22 & 2.81 \\
\hline 1.33 & 1.27 & 1.77 & 2.44 \\
\hline 1.31 & 1.51 & 1.82 & 2.25 \\
\hline 100 & 100 & 100 & 100 \\
\hline 53.5 & 29.3 & 15.8 & 12.4 \\
\hline 10.3 & 9.2 & 7.6 & 6.8 \\
\hline 33.5 & 57.5 & 73.0 & 77.2 \\
\hline 5.4 & 10.6 & 13.6 & 15.7 \\
\hline 18.1 & 32.0 & 40.0 & 38.9 \\
\hline 10.0 & 15.0 & 19.4 & 22.7 \\
\hline 2.6 & 3.9 & 3.6 & 3.6 \\
\hline 58.8 & 48.1 & 46.5 & 46.0 \\
\hline 0.8 & 5.9 & 9.7 & 9.4 \\
\hline 42.0 & 19.3 & 9.3 & 7.3 \\
\hline 2.4 & 4.4 & 4.8 & 4.8 \\
\hline 0.5 & 2.4 & 3.5 & 4.0 \\
\hline 3.3 & 3.0 & 3.7 & 3.8 \\
\hline 0.2 & 1.7 & 2.4 & 3.8 \\
\hline 0.5 & 0.6 & 2.8 & 3.6 \\
\hline 2.6 & 4.1 & 3.8 & 3.5 \\
\hline 2.1 & 3.4 & 3.2 & 3.3 \\
\hline 4.4 & 3.4 & 3.2 & 2.5 \\
\hline
\end{tabular}

Source: CAN 2000 computer programme. The groups of goods are based on the Standard International Trade Classification (sITC Rev. 2).

a Contains 45 simply processed commodities, including concentrates.

b Contains 65 elements: 35 agricultural/forestry groups and 30 others (mainly metals -except iron and steel-, petroleum products, cement, glass, etc.).

c Contains 120 groups representing the sum of ${ }^{\mathrm{d}}+{ }^{\mathrm{e}}+{ }^{\mathrm{f}}$.

d Contains 44 elements: 20 groups from the textiles and clothing division plus 24 others (paper products, glass, iron and steel, jewellery).

e Contains 58 elements: 5 groups from the motor industry, 22 from the processing industry and 31 from the engineering industry.

f Contains 18 elements: 11 groups from the electronics division plus 7 from pharmaceutical products, turbines, aircraft, instruments.

g Contains 9 groups of items not elsewhere classified (mostly from section 9).

${ }^{6}$ In Argentina and Brazil the percentage shares of the motor industry were a good deal greater in 1997 and 1998 than in 1999. In Argentina this share was $12.5 \%$ in 1998 , while in Brazil it was $8.0 \%$ in 1997 . The fall in domestic demand in those countries in the later years of the 1990s was reflected in a marked increase in idle capacity in this sector, so that the data for 1999 in table 3 do not properly reflect the major investment effort made by the motor industry in the $1990 \mathrm{~s}$. 
TABLE 5

Argentina: Aspects of its international competitiveness

in world imports, 1985-1998

I. Market share

Natural resources ${ }^{\mathrm{a}}$

Manufactures based on natural resources ${ }^{\mathrm{b}}$

Manufactures not based on natural resources ${ }^{c}$

- Low technology

- Medium technologye

- High technology ${ }^{\mathrm{f}}$

Others ${ }^{\mathrm{g}}$

II. Structure of exports

Natural resources ${ }^{\mathrm{a}}$

Manufactures based on natural resources ${ }^{\mathrm{b}}$

Manufactures not based on natural resources ${ }^{c}$

- Low technologyd

- Medium technology

- High technology ${ }^{\mathrm{f}}$

Others $^{\mathrm{g}}$

III. 10 main exports, by relative shares

081 Feeding stuff for animals (not including unmilled cereals)

333 Petroleum oils, crude

423 Fixed vegetable oils

781 Passenger motor cars

041 Wheat (including spelt) and meslin, unmilled

044 Maize (corn), unmilled

611 Leather

334 Petroleum products, refined

782 Motor vehicles for the transport of goods or materials

011 Meat and edible meat offals, fresh, chilled or frozen

\begin{tabular}{rrrr}
1985 & 1990 & 1995 & 1998 \\
\hline 0.37 & 0.36 & 0.44 & 0.51 \\
0.91 & 1.05 & 1.59 & 1.94 \\
0.47 & 0.55 & 0.64 & 0.69 \\
0.12 & 0.15 & 0.18 & 0.23 \\
0.23 & 0.26 & 0.28 & 0.27 \\
0.08 & 0.14 & 0.20 & 0.32 \\
0.08 & 0.05 & 0.04 & 0.05 \\
0.10 & 0.10 & 0.15 & 0.14 \\
& & 100 & 100 \\
100 & 100 & 100 \\
56.7 & 45.8 & 48.0 & 47.0 \\
24.8 & 26.9 & 24.0 & 21.6 \\
17.7 & 26.4 & 26.8 & 30.4 \\
9.0 & 11.9 & 10.6 & 8.7 \\
6.2 & 12.2 & 14.4 & 19.6 \\
2.5 & 2.3 & 1.9 & 2.2 \\
0.8 & 0.9 & 1.2 & 1.0 \\
43.7 & 34.4 & 44.1 & 51.7 \\
10.5 & 8.7 & 9.0 & 8.9 \\
0.7 & 1.2 & 8.8 & 7.9 \\
5.6 & 4.7 & 6.5 & 6.6 \\
0.2 & 0.3 & 2.2 & 6.1 \\
5.2 & 3.0 & 2.2 & 5.1 \\
7.1 & 2.1 & 3.6 & 5.0 \\
4.8 & 4.1 & 4.0 & 3.4 \\
4.9 & 4.1 & 2.5 & 3.2 \\
0.1 & 0.1 & 1.4 & 2.8 \\
4.8 & 6.2 & 4.1 & 2.8 \\
\hline & & &
\end{tabular}

Source: CAN 2000 computer programme. The groups of goods are based on the Standard International Trade Classification (sITC Rev. 2).

a Contains 45 simply processed commodities, including concentrates.

b Contains 65 elements: 35 agricultural/forestry groups and 30 others (mainly metals -except iron and steel-, petroleum products, cement, glass, etc.).

c Contains 120 groups representing the sum of ${ }^{\mathrm{d}}+{ }^{\mathrm{e}}+{ }^{\mathrm{f}}$.

d Contains 44 elements: 20 groups from the textiles and clothing division plus 24 others (paper products, glass, iron and steel, jewellery).

e Contains 58 elements: 5 groups from the motor industry, 22 from the processing industry and 31 from the engineering industry.

f Contains 18 elements: 11 groups from the electronics division plus 7 from pharmaceutical products, turbines, aircraft, instruments.

g Contains 9 groups of items not elsewhere classified (mostly from section 9).

over time. Mexico clearly subscribed to a model led by the exports of metal products and machinery sectors to the rapidly growing United States market. Argentina on the other hand -if we except its motor industry, which grew strongly within the framework of a highly subsidized policy- tended to concentrate on resource processing (industrial commodities).

In short, not only were there few countries of the region which were able to improve their international competitiveness in the 1990s, but those that did were only able to do so in a very limited number of production activities. These comprised predominantly, on the one hand, assembly industries making intensive use of unskilled labour, and on the other, industries processing natural resources. The former quite accurately reflects the situation of Mexico and several of the smaller Central American countries, while the latter represent the case of southern countries such as Argentina, Chile, Brazil or Uruguay.

There was also an appreciable improvement in the productivity and international trade insertion of the motor industry -and in the case of Brazil of the aircraft

SECTORAL REGIMES, PRODUCTIVITY AND INTERNATIONAL COMPETITIVENESS • JORGE KATZ AND GIOVANNI STUMPO 
industry too- ${ }^{7}$ which received preferential treatment from the economic authorities.

Another fundamental feature of the process we are describing concerns the nature of the economic agents which have led the processes of change. In the maquila model, transnational enterprises predominate, and there are few large domestic conglomerates which have managed to incorporate themselves into the process as suppliers of parts or intermediate inputs (Mortimore and Peres, 2001; Garrido, 2000; Kulfas, 2000). ${ }^{8}$ In the case of the growth model based on the processing of natural resources, in contrast, it is big local conglomerates which have played a leading role. In both scenarios, small and medium-sized locally owned enterprises, on the one hand, and the group of State firms, on the other, lost relative participation in recent years. ${ }^{9}$ Once again, it is a question of dominant trends: examples can be found of transnational corporations which have specialized in the processing of natural resources and of countries where small and medium sized enterprises as a whole have not significantly lost (or have even marginally improved) their share in GDP (Peres and Stumpo, 2000).

\section{The relative productivity gap}

Let us begin by looking at the aggregate performance of the manufacturing sector of various countries of the region in comparison with that of the United States in the period 1970-1998 and in various sub-periods of this two-decade-long global stretch of time.

Before embarking on the analysis of the indicators contained in table 6 it is important to keep in mind that the United States economy, which is used here as a benchmark for evaluating the evolution of the labour

\footnotetext{
${ }^{7}$ In this respect, it is worth analysing in detail the case of Embraer, which is currently the leading Brazilian exporter of manufactures, has gone through various stages of evolution in its links with the Brazilian public sector, has given evidence of a notable long-term process of accumulation of its own technological capabilities which has served as the basis for its present export success (see Goldstein, 2000).

${ }^{8}$ An interesting debate is currently under way on the degree to which the great Mexican economic groups have managed to enter the first "ring" of suppliers of Mexican automobile assembly firms: something which does not seem to have been accomplished by local auto parts suppliers in Argentina or Brazil, where takeovers of such firms by big transnational corporations have become a byword in recent years (see Brown, 2000).

9 The available figures show a wide variety of situations among the different countries, however (see Peres and Stumpo, 2000).
}

productivity of the Latin American countries, grew faster in the 1990s than its historical rate.

The figures in table 6 show that between 1970 and 1998 no country of the region reached growth rates of industrial labour productivity which were higher than those of the United States manufacturing sector. ${ }^{10}$ Consequently, not only was the disparity quite large in absolute terms to begin with but we also found a longterm tendency towards a widening of the productivity gap.

It may be seen from table 7 that all the countries under examination show lower levels of relative productivity in 1998 (compared with the United States) than in 1970. Here too, however, there are differences between countries: the relative loss of ground was clearly smaller in the case of Brazil and, above all, Argentina. These two countries (together with Uruguay up to 1996) are the only ones which showed a clear tendency to narrow the productivity gap during the 1990s. As already noted, however, even in these cases the growth in relative productivity was not enough to regain the values of the early 1970 s and to make up for the serious loss of ground suffered in this respect in the 1980s. It should also be noted that -at least in Argentina- the reduction in the relative productivity gap in the 1990s was due essentially to the restructuring of enterprises and the closure of less competitive firms rather than to a generalized trend towards new investments in industry.

This suggests that the structural reforms favouring competitiveness induced a certain amount of transformation of the production structure, but did not succeed in bringing labour productivity in manufacturing closer to that of the corresponding sector in the United States.

Figure 3 shows that the reduction in the relative labour productivity gap has tended to be greater in the motor industry (which received preferential treatment from the economic authorities in all the countries considered) and in the industrial sectors processing natural resources, especially those producing pulp and paper, chemical and petrochemical products and nonferrous metals (i.e., the branches identified in the figure as "Other N.R.").

In contrast to the above, the industrial activities making heavy use of unskilled labour and catering for the local markets, producing footwear, clothing,

\footnotetext{
10 The country which came closest to this was Argentina, with an average annual growth rate of $3.7 \%$, as compared with $3.9 \%$ in the United States.
} 
TABLE 6

Production, employment and labour productivity

in Latin American manufacturing, 1970-1990 and 1990-1998

(Annual average growth rates)

\begin{tabular}{|c|c|c|c|c|c|c|}
\hline & \multicolumn{2}{|c|}{ Production } & \multicolumn{2}{|c|}{ Employment } & \multicolumn{2}{|c|}{ Productivity } \\
\hline & $1970-1990$ & 1990-1998 & $1970-1990$ & 1990-1998 & $1970-1990$ & 1990-1998 \\
\hline Argentina & -0.3 & 5.2 & -2.3 & -2.5 & 2.0 & 7.9 \\
\hline Bolivia & 2.1 & 3.9 & 2.6 & 4.1 & -0.5 & -0.1 \\
\hline Brazil & 4.4 & 0.1 & 3.2 & -5.9 & 1.2 & 6.4 \\
\hline Chile & 1.8 & 4.8 & 0.4 & 0.3 & 1.4 & 4.4 \\
\hline Colombia & 3.6 & 1.5 & 1.8 & -1.8 & 1.8 & 3.3 \\
\hline Costa Rica & 4.8 & 4.2 & 8.0 & 1.8 & -2.9 & 2.0 \\
\hline Ecuador & 4.5 & 4.0 & 4.4 & 2.9 & 0.1 & 2.7 \\
\hline El Salvador & -0.3 & 5.8 & -1.8 & $\ldots$ & 1.8 & $\ldots$ \\
\hline Honduras & 4.6 & 4.2 & 4.9 & $\ldots$ & -0.4 & $\ldots$ \\
\hline Mexico & 4.1 & 3.7 & 2.1 & 1.0 & 1.9 & 2.7 \\
\hline Panama & 1.6 & 4.7 & 2.6 & 0.5 & -1.0 & 4.2 \\
\hline Peru & 0.7 & 4.4 & 3.1 & 2.0 & -2.4 & 3.1 \\
\hline Uruguay & 1.1 & 0.7 & 3.0 & -8.0 & -1.8 & 8.2 \\
\hline Venezuela & 3.5 & 2.7 & 3.8 & -1.0 & -0.3 & 4.8 \\
\hline United States & 3.5 & 4.3 & -0.2 & -0.2 & 3.7 & 4.5 \\
\hline
\end{tabular}

Source: The PADI computer programme.

TABLE 7

Latin America: Relative labour productivity of industry compared with the United States manufacturing sector

\begin{tabular}{lrrrr}
\hline & 1970 & 1980 & 1990 & 1998 \\
\cline { 2 - 5 } Argentina & 50.2 & 46.6 & 36.4 & 46.9 \\
Brazil & 35.4 & 28.3 & 21.7 & 25.0 \\
Chile & 46.2 & 42.2 & 29.5 & 29.3 \\
Colombia & 40.1 & 30.7 & 27.3 & 24.8 \\
Costa Rica $^{a}$ & - & - & 15.0 & 13.8 \\
Jamaica $^{a}$ & 28.0 & 16.5 & 9.3 & 8.8 \\
Mexico & 28.7 & 25.5 & 20.3 & 17.6 \\
Peru $^{\mathrm{b}}$ & 40.4 & 30.0 & 1.9 & 11.4 \\
Uruguay $^{\mathrm{c}}$ & 43.0 & 21.7 & 1.7 & 17.3 \\
\hline
\end{tabular}

Source: The PADI computer programme.

a Data up to 1992 . $^{\text {b }}$ Data up to 1996 . $^{\mathrm{c}}$ Data up to 1995.

furniture, etc., turned in a poorer relative performance and were unable to withstand the competition of China. A particularly poor performance was registered by the activities making intensive use of engineering services and engaging in research and development activities (capital goods, the electronics industry, scientific instruments). These activities faced a massive increase in imports, facilitated by the greater external trade openness, and have clearly lost ground with respect to the international technological frontier.

In other words, what happened as regards the relative labour productivity gap in the 1990s confirms that the "winning" sectors, i.e., those which managed to come somewhat closer to the international productivity frontier, were those which were favoured by industrial policy, which benefitted from intraregional trade agreements, or which fitted in with the pattern of "natural" comparative advantages of the region. These three manufacturing categories currently make up the new production specialization pattern of the various Latin American countries. In contrast, the industries making intensive use of technological knowhow and spending money on research and development have clearly lagged behind, as so also have, to a lesser extent, the industries making intensive use of labour to produce wage goods for the domestic market. While the latter industries have more and more difficulty in competing with imports from labour-surplus countries, the former have the same problem with imports from technologically more mature economies.

To sum up, the sectors which are doing better in relative terms are: i) the industrial sectors which have received preferential treatment from economic authorities; ii) assembly industries producing for the United States market; and iii) industries processing natural resources and enjoying static comparative advantages. In contrast, those which have lost relative ground internationally are: i) industrial branches making intensive use of knowledge, and ii) those making intensive use of unskilled labour producing wage goods for the domestic market, which in the

SECTORAL REGIMES, PRODUCTIVITY AND INTERNATIONAL COMPETITIVENESS • JORGE KATZ AND GIOVANNI STUMPO 
FIGURE 3

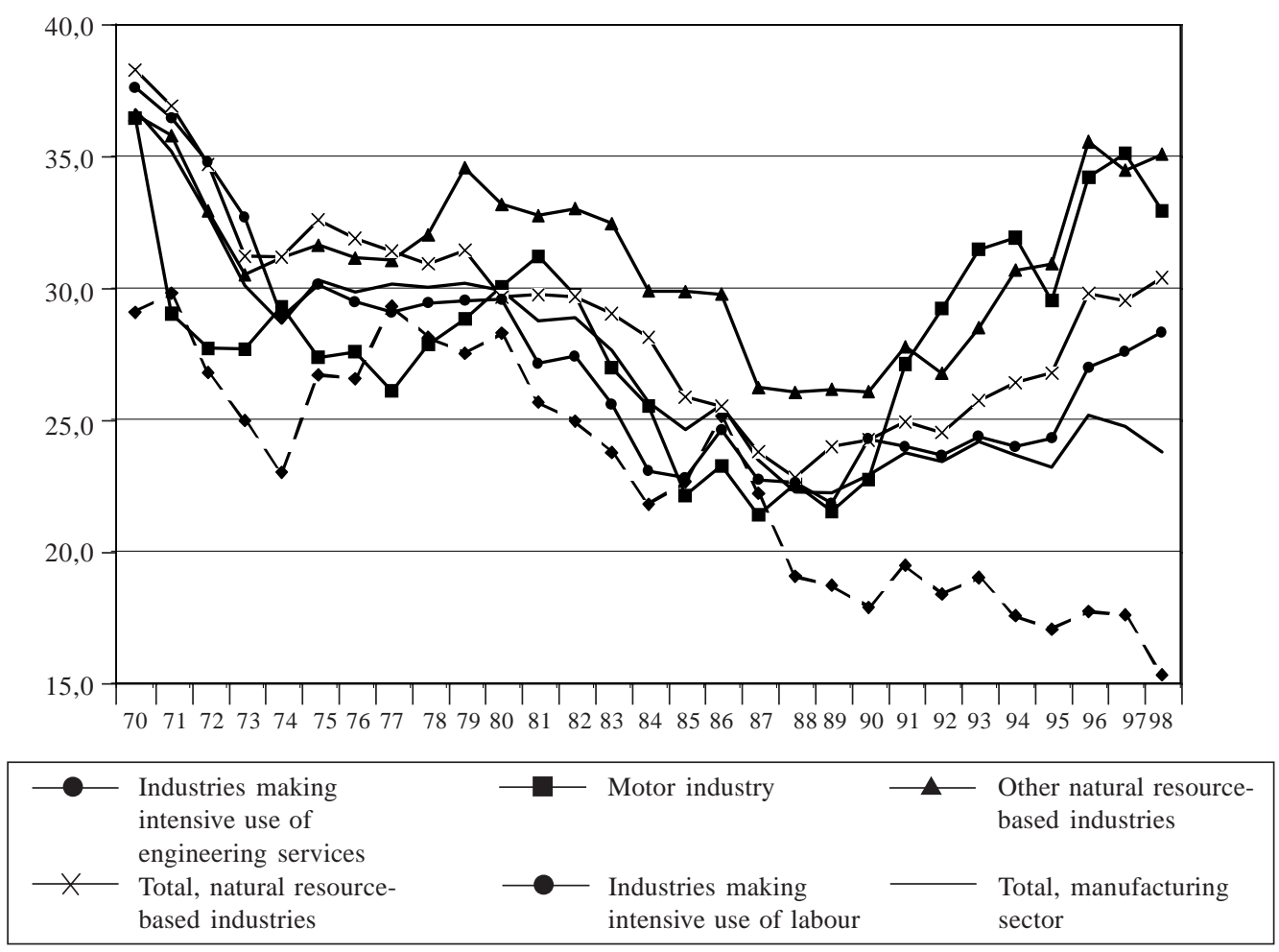

Source: The PADI computer programme.

present circumstances can hardly face the competition from Chinese firms.

What types of firms tend to predominate in the "winning" and "losing" sectors? Local subsidiaries of foreign corporations and big locally owned conglomerates predominate in the first group, while small and medium-sized family-owned firms are typical members of the "losing" set.

Figure 3 shows another fact of considerable interest: only the motor industry is now closer to the international technological frontier than it was twenty years earlier, in the early 1980s. This enables us to gain an idea of the enormous amount of ground the region lost through the debt crisis and subsequently throughout the 1980s. If we also take into account the crucial role played by industrial policy in the revitalization of the motor industry, we cannot fail to be struck by the dubious capacity of conventional market mechanisms to further the growth of the sectors with the greatest content of technological knowledge and domestic added value.
This is a serious conclusion to reach, to be sure, because it questions much of the conventional wisdom of the more orthodox sectors of our profession. Nevertheless, we believe that the results set forth here give a fairly credible picture of what has happened in the industrial sector of Latin America in recent years, and they will undoubtedly be useful when considering public policy matters, as we will do later in this article.

The results presented so far also clearly show that there are great differences among industries and types of enterprises in terms of their pattern of adaptation to the new rules of the game. It is precisely this observation which suggests that we should progress to the mesoeconomic and microeconomic aspects of the present structural transformation if we wish to understand more fully what has happened in recent years in Latin America. The transition to a more open and deregulated industrial organization model has been accompanied by many changes in what we have called here the technological and institutional "regimes" of each activity.

SECtoral REgimes, PROdUCTIVITY AND INTERNATIONAL COMPETITIVENESS • JORGE KATZ AND GIOVANNI STUMPO 
III

\section{Meso-economic and microeconomic aspects of the structural change process}

\section{The empirical evidence}

In almost all sectors of production, firms which could not adapt to the new rules have disappeared, new firms have entered the market, bringing with them new technologies (products, processes and organization of work), and there have been changes -sometimes of a radical nature- in the institutional and regulatory framework in which the sector operates (changes in patent law, property rights over natural resources, fiscal treatment, etc.). At the same time, the degree of economic concentration has increased and in each market the competition from foreign firms has also become stronger. Firms have reduced their degree of vertical integration and have moved towards just-intime production organization techniques, interacting in a very different way with the international environment.

All this suggests that in each field of production a new production organization model has emerged, i.e., a new way of creating economic surplus and distributing it among the different economic agents and also between the local economy and the foreign sector. This is exactly what economic globalization means: that the different sectoral technological and competitive regimes become more closely linked with external forces.

Let us take as an example the steel industry -ISIC 371 (iron and steel)-, in which Argentina, Colombia and Brazil are clearly coming closer to the international technological frontier, while Chile and Mexico are also doing well, though rather less spectacularly. In other words, all the countries studied here managed to improve their position relative to the United States in this field during the period under examination. To what was this due? The failure of the United States in the iron and steel field throughout the 1980s was undoubtedly very serious and is well documented in the literature of the 1970s and 1980s, highlighting the enormous difficulty experienced by the United States steel companies in keeping up with the rate of innovation of their European or South Korean competitors. This obviously cannot be the whole explanation for what happened, however. What we are interested in analysing here are the changes that took place within Latin American countries.

Let us take the case of Argentina, for example. We know that the Argentine steel industry underwent a major restructuring process -including the privatization of a large State-owned steelworks- during the 1980s and 1990s. This process involved: i) "births" and "deaths" of enterprises; ii) changes in the institutional fabric of the sector; and iii) the transnationalization of the industry or, in other words, its generalized orientation towards the external sector not only in terms of imports and exports but also in terms of foreign direct investment and its gradual insertion in the community of international "global players". All this was reflected in a period of profound structural changes and the gradual construction of a new competitive regime which is certainly very different from that prevailing during the import substitution industrialization period.

Of the 59 industrial steelworks that Argentina had in 1975, only 26 were still operating in the 1990s. The State-owned plant -Somisa S.A.- had been acquired, partially dismantled and rehabilitated by Techint S.A., one of the two large locally-owned conglomerates that currently control the industry. In a rapid internationalization programme, that same group had also acquired Tamsa in Mexico and Sidor in Venezuela, as well as other firms, while at the same time it formed strategic alliances with big European steelmaking groups in order to gain control of the State-owned steelworks privatized by the Italian government. In other words, in spite of the vicissitudes of the Argentine macroeconomic picture and the fall in investment suffered by that country in the 1980 s, Techint S.A. carried through a major internationalization process in the 1980s and set itself up as a "global player" on the world scene, with diversified activities all over the world in the steel industry in general and in the production of seamless tubes in particular.

As well as the "birth" and "death" of enterprises and the changes in market structure and performance -including the privatization of a State-owned steelworks and the total disappearance of the State as an important agent in this market- changes were also taking place

SECTORAL REGIMES, PRODUCTIVITY AND INTERNATIONAL COMPETITIVENESS • JORGE KATZ AND GIOVANNI STUMPO 
in the institutional structure, in the mechanisms for the training of skilled human resources, and in the creation of new technological knowledge within the industry, along with a marked change in the pattern of comparative advantages and of insertion in world trade. Techint S.A. made progress in the establishment of a world-class research and development infrastructure, acquired railways and ports, began to participate in energy production, and was gradually building up a new business management model which was younger and more professionalized than that which had previously characterized the sector. As it grew, it quite naturally became linked with the exterior more than with the domestic environment. As it became a global player it gradually left behind its past as an import substitution firm and steadily took on characteristics of present-day capitalism. Its former image belonged to the international climate of the post-war years, while its new image belongs to the competitive world of globalization.

This completes our description of the example of the steel industry, which we now intend to use as the basis for an exercise in "appreciative theorization". Generalizing on the basis of this case, we can say that all forms of productive activity may be seen as an aggregate of firms (public and private), regulatory agencies, and rules and standards of behaviour which, together, define a "competitive and technological regime", unique and particular in many respects, which is different from that prevailing in other sectors of production. This regime fits in with the global pattern of incentives prevailing in society, but it also depends on the specificities that each production sector has developed over time and, ultimately, on the nature of the individual actors participating in it. Comparative advantages and forms of globalization do not only reflect relative prices but also institutional factors, business strategies and the technological changes that the international production frontier undergoes exogenously. Among the institutions involved are the banks and financial agents which provide resources to finance the long-term investment programmes of the sector. There are also the universities and technical schools responsible for training the human capital required by industry, the engineering firms which support the technical management of enterprises, customs services, ports, and firms that supply energy and transport services. In one way or another, each of these links conditions the day-to-day operation of the sector. This "collection" of actors "stores up" a whole range of technological know-how, legal frameworks and rules of behaviour which determine the greater or lesser degree of efficiency attained by the sector at any given moment in time. When we say that competitiveness is systemic, this is exactly what we mean: in order to be efficient, a production sector must operate in a context which is efficient globally.

The recent structural reforms have affected the systemic competitiveness of the whole structure of production through the changes they have brought about in the structure and performance of the multiple sectoral regimes and in their linkages with domestic and external institutional, economic and technological forces. Each line of production, including its firms, its technological know-how, its institutional framework and its degree of internationalization, tends to change as a function of the changes in the global system of incentives prevailing in society. Only a proper understanding of the way this takes in each sectoral and national context will enable us to understand the new forms of operation of Latin American capitalism of recent years.

\section{The forces behind changes in sectoral regimes}

\section{a) "Birth" and "death" of enterprises}

A first important topic related with the impact that the structural reforms have had on almost all types of production activities is that of the death and disappearance of enterprises, on the one hand, and the entry of new firms into the market on the other. Thus, when the economy is opened up to outside competition some firms are forced to leave the market because they are unable to adapt to the new rules of the game, while new firms may enter the market in their place. Such births and deaths may take place at very different points in time, that is to say, in very different phases of each sector's adaptation to the new rules. An important role is played in this respect both by the relations between micro and macro variables and by the changes which take place simultaneously, but independently of each other, in the institutional environment of each sector. A macro economy with a high degree of uncertainty does not stimulate the creation of new industrial plants. A procyclical institutional situation, on the other hand -for example, one that favours long-term investment through suitable reorganization of the capital marketcan help to foster the installation of new production capacity.

We can see from table 8 that the Argentine steelworks which have disappeared have mostly been

SECTORAL REGIMES, PRODUCTIVITY AND INTERNATIONAL COMPETITIVENESS • JORGE KATZ AND GIOVANNI STUMPO 
TABLE 8

Argentina: Structural change, "births" and "deaths of companies in the steel industry, 1975-1992

\begin{tabular}{|c|c|c|c|c|c|}
\hline & 1975 & 1980 & 1985 & 1990 & 1992 \\
\hline Integrated firms & $\begin{array}{l}\text { Alt. Horn. Zapla } \\
\text { Somisa }\end{array}$ & $\begin{array}{l}\text { Alt. Horn. Zapla } \\
\text { Somisa } \\
\text { Acindar } \\
\text { Siderca }\end{array}$ & $\begin{array}{l}\text { Alt. Horn. Zapla } \\
\text { Somisa } \\
\text { Acindar } \\
\text { Siderca }\end{array}$ & $\begin{array}{l}\text { Alt. Horn. Zapla } \\
\text { Somisa } \\
\text { Acindar } \\
\text { Siderca }\end{array}$ & $\begin{array}{l}\text { Aceros Zapla } \\
\text { Aceros Paraná } \\
\text { Acindar } \\
\text { Siderca }\end{array}$ \\
\hline Total & 2 & 4 & 4 & 4 & 4 \\
\hline Semi-integrated firms & $\begin{array}{l}\text { Aceros Bragado } \\
\text { Aceros Ohler } \\
\text { Acinda } \\
\text { Cura Brothers } \\
\text { Gurmendi } \\
\text { La Cantábrica } \\
\text { Mairimi\&Sinai } \\
\text { Santa Rosa } \\
\text { Siderca } \\
\text { Tamet }\end{array}$ & $\begin{array}{l}\text { Aceros Bragado } \\
\text { Gurmendi } \\
\text { La Cantábrica } \\
\text { Santa Rosa } \\
\text { Tamet }\end{array}$ & $\begin{array}{l}\text { Aceros Bragado } \\
\text { Tamet }\end{array}$ & $\begin{array}{l}\text { Aceros Bragado } \\
\text { Tamet }\end{array}$ & Aceros Bragado \\
\hline Total & 10 & 5 & 2 & 2 & 1 \\
\hline Total rolling mills & 47 & 38 & 36 & 33 & 21 \\
\hline Total, whole industry & 59 & 47 & 42 & 39 & 26 \\
\hline
\end{tabular}

Source: Azpiazu and Basualdo (1997).

small and medium-sized non-integrated enterprises, and they have mostly disappeared in the early stages of the country's macroeconomic adjustment process. ${ }^{11}$ In contrast, the "births" seem to take place in later stages of the cycle, when the macro economy entered on a stage of stabilization and business expectations once again favoured longer-term investment processes and technological modernization programmes.

Apart from the question of the point in time at which the births and deaths of enterprises take place, we can also see that the process has a clear impact on the average size of the plants in the industry, on labour productivity, and on the index of economic concentration prevailing in the activity. This is shown in stylized form in figure 4 . The vertical axis measures

${ }^{11}$ The weakness of local anti-monopoly legislation may be viewed as part of the institutional situation in which the restructuring of this industry takes place. Techint S.A. bought and then closed down several of the small and medium-sized steelworks which disappeared from the market in the 1980s. An institutional situation which was firmer as far as the protection of competition was concerned would assuredly have given rise to a different type of restructuring of the sector from that which finally occurred in this branch of production. the average productivity of the branch, while the horizontal axis shows the average size of the plants. The first distribution describes the situation of the industry before the opening of the economy, while the second one represents the industry after trade liberalization has taken place.

We note that the improvements in average productivity are due both to the deaths -which we may assume to correspond to the smaller and more inefficient enterprises of the sector- and to the births, which we may assume to be associated with the entry into the market of new firms of larger average size which bring with them production and organizational technologies much closer to the international "state of the art".

The sectoral restructuring process we have been describing is associated with an increase in the degree of economic concentration, but also probably with a reduction in the index of relative heterogeneity among plants within the sector. The increase in economic concentration in the sector should not necessarily be seen as an indication that the degree of monopoly is increasing, however. It should be remembered that, along with the restructuring of the sector, the opening up of the economy is increasing the disciplinary effect

SECTORAL REGIMES, PRODUCTIVITY AND INTERNATIONAL COMPETITIVENESS • JORGE KATZ AND GIOVANNI STUMPO 
FIGURE 4

Births and deaths of enterprises and average productivity of a branch of production

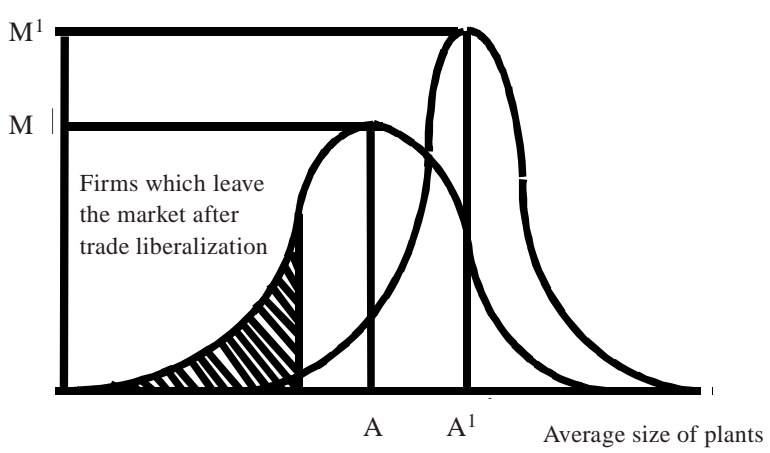

$M=$ Average productivity of sector before trade liberalization efforts $\mathrm{M}^{1}=$ Average productivity of sector after trade liberalization

Source: Prepared by the author.

of outside competition on local firms, making it harder for them to capture monopoly rents. This effect will undoubtedly differ a great deal between branches of activity, however, depending on the greater or lesser role, in each case, that brand names, patent rights and other such "institutions" play in strengthening the capacity of firms to differentiate their products from imported ones. An extreme example of this is the case of the pharmaceutical industry, where consumers display various forms of "loyalty" to brand names and imperfect information of the consumer is a proverbial feature of the industrial organization model of the sector. This has enabled pharmaceutical entrepreneurs to capture monopoly rents even in the context of trade liberalization (Katz, 1998). This obviously does not apply, however, to less differentiated products which are more in the nature of "commodities".

b) Rejuvenation of the stock of machinery and equipment and displacement of local engineering services

The fact that imported capital goods have become cheaper because of greater trade openness has favoured their use instead of locally-made machinery and equipment, and the same thing has happened with respect to local engineering services, which were previously used in-plant to extend the life cycle of the available equipment. In other words, the structural reforms designed to increase competitiveness have led on the one hand to a certain degree of rejuvenation of the machinery and equipment available in industry, and on the other to the gradual externalization of the sources of technological progress underlying the increases in productivity.

The privatization of public enterprises has operated in the same direction in recent years -i.e., lowering the average age of the stock of capital goods and facilitating the expulsion of skilled labour (as for example in the telecommunications or energy sectors). In a number of countries of the region, there has even been a tendency in these sectors to close down the engineering and project design departments which State enterprises had created during the import substitution years. A similar process seems to be taking place in many local subsidiaries of big transnational groups, which in recent years have started to operate in real time, working "on line" with their respective headquarters. Many of them have radically changed their past forms of production organization and technological behaviour. It now seems less necessary to them to adapt technology to the local environment as they did in the past; the proportion of imported inputs used in production has increased and there has been a transition towards a strategy of almost total assimilation of the range of products manufactured locally with those of the parent firm. ${ }^{12}$

In all these cases we are faced with the paradox that while progress is being made towards product designs and production technologies which are closer to the world technological frontier, at the same time there is a growing trend towards the assembly of imported components, with less domestic value added.

In a recent study, Cimoli and Katz (2001) illustrate this phenomenon through a model which is summarized in figure 5. In quadrant 1 we have a transformation function with two production factors: domestic capital (KD) and foreign capital (KF). The curves in this quadrant show the various combinations of machinery and equipment, of local and imported origin, that firms can choose at different relative prices. The relation between the use of foreign capital and the expulsion of human resources observed in the plants is shown in quadrant 2. Quadrant 4 describes the relation between the use of foreign capital and imports. Curve FF represents a neutral response to prices on international markets. A movement towards the abscissa will restrict imports of capital goods. If the curve moves in the opposite direction, however, there will be more incentives for the importation of such goods.

12 The motor industry is a typical case in this respect (see Katz, 1998). 
FIGURE 5

Lowering of cost of imported capital goods and obsolescence of local human capital

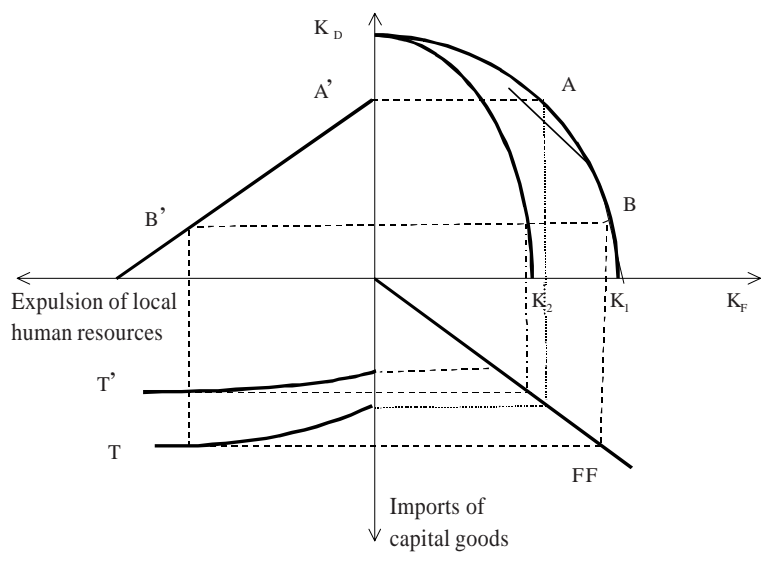

Source: Cimoli and Katz (2001).

A fall in the relative price of imported capital goods compared with locally-made ones (as a result, for example, of a reduction in import tariffs) will cause a movement from A to B. In general, using more machines means that less labour will be needed, but as the imported equipment "embodies" some of the skills of local skilled labour, its importation will also mean that fewer skilled human resources are needed in-plant. Furthermore, some maintenance efforts which were previously made in order to extend the life cycle of the machinery also become unnecessary because of the greater accessibility and lower price of imported equipment. It makes less sense than before to maintain engineering departments of the size previously considered to correspond with the scale and level of activity of the plants, so that many of them are simply eliminated. Curve $\mathrm{T}$ in quadrant 3 represents the solution of the model: greater imports of capital goods due to the reduction in their relative prices leads to the expulsion of human capital.

The figure also shows a situation in which the foreign capital incorporates a much better "vintage" of technology, causing the curve in quadrant 1 to shift towards the root. This means that the same level of production can be achieved with fewer (imported) machines than before. If more machinery is imported than is needed to manufacture the original amount of output, the displacement of skilled labour from the plant will result even larger. Curve $\mathrm{T}$ will shift to T', indicating that the same amount of expulsion of human resources can be achieved with fewer imports of machines. If output increases with respect to the initial output, the "destruction" of local human capital will be even greater.

In an open economy the life cycle of machinery tends to be shorter, the rate of obsolescence higher and the replacement of equipment faster than in an economy which is less open, where importing machinery is more expensive and more difficult (because of non-tariff restrictions). This brings in an important new phenomenon: as the production of technological know-how does not constitute part of the local comparative advantages, firms will increasingly resort to the importation of technological knowledge "embodied" in new equipment, instead of using locally-produced machinery and engineering services. In these circumstances, it will be more difficult to build up local technological capacity, and this situation becomes even worse when, because of the privatization of State enterprises and the gradual transition to internationally integrated systems of production in large MNCs, engineering and project planning activities tend to be transferred to the head offices of the parent firms. In the new pattern of production specialization resulting from mergers or from the privatization of public companies, the local firms tend to concentrate on tasks involving less local added value. They choose to operate closer to assembly activities or the primary processing of natural resources than to engage in processes with a higher local added value (Cimoli and Katz, 2001).

This phenomenon also has implications for the trade balance, as we see in section d below.

On the other hand, just as there is some evidence of forces associated with the sectoral restructuring process described above which can destroy domestic technological capacity, there is also evidence that that process leads to the appearance of new activities (for example, production services such as packaging, development of computer programmes, real-time transport and distribution services, international marketing, etc.) which involve a gradual transition towards a more sophisticated technological and competitive regime closer to the international "state of the art".

In short, sectoral restructuring is intimately associated with a process of creative destruction of both the physical and human capital linked with a given sectoral regime. 


\section{c) The restructuring of institutions}

The process described above has a clear parallel in the institutional sphere, where different forms of partial approximation to the model of production organization of the developed countries may also be noticed. The strengthening of property rights in the field of natural resources (some countries have even incorporated these rights in their Constitutions), the deregulation of many markets (capital and labour markets, for example), stronger intellectual property rights, and the assurance by law that foreign capital will receive the same treatment as domestic capital all form part of a broad network of new institutions which represents a gradual process of "levelling the playing field", as this is sometimes called today.

The changes in the international agenda in this respect began to take shape in the mid-1980s and were connected on the one hand with the 1984 United States Trade and Tariff Act and on the other with the initiation in 1986 of the multilateral negotiations on intellectual property rights, which finally resulted in the TRIPS (Trade-Related aspects of International Property Rights) agreement of the Uruguay Round of GATT, signed in Marrakesh in $1994 .{ }^{13}$ It was precisely from that time onward that the process of institutional convergence towards the new set of disciplines (TRIPS, TRIMS (TradeRelated Investment Measures) and GATS (General Agreement on Trade in Services) began to gather pace. In a recent study, Sercovich holds that the commitment to institutional convergence is undeniable. Of the 109 developing countries and transitional economies which have undergone pro-competitive reforms since the 1980s, 75 did so from 1989 onwards. Furthermore, 107 of the 134 members of the WTO are developing or transitional economies, while 28 -including China, the Russian Federation and Taiwan- are actively negotiating their entry under special conditions. The TRIMS agreement provides that by 2002 the developing countries must abolish all restrictions on foreign investment which affect, among other things, export subsidies and local content requirements (Sercovich, 1999).

13 The "Statement of Views of the European, Japanese and United States Business Communities" issued in June 1988 as a preparatory base of GATT on intellectual property rights says: Inappropriate and ineffective protection of intellectual property rights has given rise to serious distortions in international trade ..... [those] rights form the basis for international competitiveness ....". Much of the explanation for the changes which have taken place in the international agenda during those years may be found in the political
In short, the restructuring of the sectoral technological and competitive regimes we have been describing involves not only a complex episode of changes in the structure and performance of each sector of production -through births and deaths of enterprises, increases in the degree of economic concentration, etc.- but also profound changes in the institutional and regulatory environment in which each activity operates.

\section{d) Linkages with the external sector}

The changes in the global incentives regime prevailing in society also cause the relationship with external forces and linkages to change in a dramatic way.

In view of the changes in relative prices that take place in the economy as a result of trade liberalization, the greater degree of vertical disintegration now observed in production processes and the increasingly important role played by MNCs operating under integrated international production systems, it may be expected that many inputs that were previously made locally (or subcontracted to local firms) are now imported. In order to import them it becomes necessary to export more. In other words, it would seem reasonable to expect that the new technological and competitive regimes will give rise to a greater orientation towards the exterior in terms of both imports and exports. It also seems reasonable to expect that there will be big differences in the way each industry restructures its pattern of linkages with the exterior. We know, for example, that industrial sectors which make intensive use of technological knowledge and research -such as the pharmaceutical, electronics or capital goods sectors- have found it more efficient, when tariff protection was reduced, to go back to buying intermediate inputs and raw materials from their respective parent firms instead of continuing to produce them locally. We also know that in order to be able to import those intermediate inputs many firms have been obliged to export (or have been pressed to do so by the economic authorities, as in the case of the motor industry).

lobbying carried out in Washington by the United States pharmaceutical industry, whose international competitiveness was seriously affected by the weakness of patent legislation in countries such as Argentina, Brazil or India. See in this respect Olson (1991) and, with regard to pharmaceutical matters in general and the erosion of the United States' comparative advantages because of the slower rate of innovation of its pharmaceutical industry in the 1970s, see Katz (1974).

SECtoral REgIMES, PROdUCTIVITy AND INTERNATIONAL COMPETITIVENESS • JORGE KATZ AND GIOVANNI STUMPO 
In other words, the change in the production organization model (vertical disintegration), the tendency to operate under the form of integrated international production systems, tariff reductions, government pressures or contraction in domestic demand have caused the new technological and competitive regimes to be "naturally" more linked with the exterior than before. This brings with it the possibility that those regimes may involve foreign exchange deficits, i.e., that they may generate deficits on their external trade balances. This gives rise to an important new issue of micro-macro coordination: a global trade balance seems increasingly difficult to sustain under present circumstances.

The following tables show that this is actually taking place, though some countries seem to be more affected than others by these new trends.

The evidence shows that the transition to more open sectoral regimes has been much stronger in Mexico than in the other countries. The role of the North American Free Trade Agreement and the pressure that may be expected from operating in increasingly close integration with the world's largest economy -which also kept up a rapid growth rate throughout almost the whole of the decade- undoubtedly explain the big increase in both the import and export coefficients in the case of Mexico, especially after the devaluation in late 1994. We can also see that, although both indexes increased considerably, the new sectoral regimes in Mexico were more oriented towards exports than imports, which represents a major difference with the cases of Argentina, Brazil or Colombia.

This explains (table 10) why Mexico achieved a positive trade balance in the manufacturing sector from 1991 on. In contrast, although MERCOSUR has given rise to considerable increases in intra-regional trade, its impact on the degree of external openness of the new sectoral competitive regimes of Argentina, Brazil or Colombia has been significantly less than in the case of Mexico and there has been a stronger orientation towards imports, reflected in significant trade balance deficits. As our reasoning earlier shows, this deficit has been particularly marked in those industries making intensive use of technological and engineering services and research and development, i.e., those manufacturing capital goods, electronic goods and pharmaceutical inputs. As we argued earlier, in all these cases the new sectoral regimes have tended to cause a disproportionate increase in their demand for imports. Their revealed competitiveness has clearly fallen further behind after trade liberalization.

The data show a clear deterioration in the trade balance during the 1990s, except for Mexico. Brazil

TABLE 9

Latin America (five countries): Export and

import coefficients of the manufacturing sector

\begin{tabular}{|c|c|c|c|c|c|}
\hline & 1970 & 1980 & 1990 & 1998 & 1999 \\
\hline \multicolumn{6}{|l|}{ Argentina } \\
\hline Export coefficient & 7.6 & 6.0 & 16.0 & 17.1 & 16.8 \\
\hline Import coefficient & 10.3 & 11.3 & 6.8 & 30.7 & 27.6 \\
\hline \multicolumn{6}{|l|}{ Brazil } \\
\hline Export coefficient & 7.3 & 9.1 & 7.7 & 10.2 & 13.6 \\
\hline Import coefficient & 8.4 & 7.1 & 4.8 & 13.0 & 15.3 \\
\hline \multicolumn{6}{|l|}{ Mexico } \\
\hline Export coefficient & 3.4 & 2.9 & 9.5 & 42.0 & 51.7 \\
\hline Import coefficient & 9.7 & 15.1 & 17.8 & 45.2 & 49.4 \\
\hline \multicolumn{6}{|l|}{ Chile } \\
\hline Export coefficient & 3.2 & 10.2 & 13.2 & 15.8 & 17.5 \\
\hline Import coefficient & 21.0 & 30.1 & 34.3 & 44.0 & 35.8 \\
\hline \multicolumn{6}{|l|}{ Colombia } \\
\hline Export coefficient & 2.9 & 6.6 & 10.1 & 13.8 & \\
\hline Import coefficient & 22.9 & 22.4 & 24.0 & 42.4 & \\
\hline
\end{tabular}

Source: The PADI computer programme.

SECTORAL REGIMES, PRODUCTIVITY AND INTERNATIONAL COMPETITIVENESS • JORGE KATZ AND GIOVANNI STUMPO 
TABLE 10

Latin America (five countries): Trade balance of the manufacturing sector as a whole and the sectors making intensive use of technology

\begin{tabular}{|c|c|c|c|c|c|}
\hline \multirow{2}{*}{ Countries } & \multicolumn{5}{|c|}{ Trade balance } \\
\hline & 1970 & 1980 & 1990 & 1998 & 1999 \\
\hline \multicolumn{6}{|l|}{ Argentina } \\
\hline Sectors making intensive use of technology & -519.89 & -4214.3 & -649.82 & -13050.1 & -10357.00 \\
\hline Manufacturing sector as a whole & -382.4 & -4237.21 & 4592.41 & -13107.8 & -9431.69 \\
\hline \multicolumn{6}{|l|}{ Brazil } \\
\hline Sectors making intensive use of technology & -1051.16 & -2136.85 & -947.89 & -15855.5 & -12194.50 \\
\hline Manufacturing sector as a whole & -291.13 & 3478.45 & 9252.51 & -10918.3 & -4607.14 \\
\hline \multicolumn{6}{|l|}{ Mexico } \\
\hline Sectors making intensive use of technology & -1201.92 & -8237.65 & -6800.07 & 5894.14 & 22143.48 \\
\hline Manufacturing sector as a whole & -1404.33 & -13193.1 & -11912.3 & -7929.67 & 6327.72 \\
\hline \multicolumn{6}{|l|}{ Chile } \\
\hline Sectors making intensive use of technology & -437.74 & -1804.3 & -3272.27 & -7664.89 & -5188.14 \\
\hline Manufacturing sector as a whole & -643.29 & -2357.18 & -3439.62 & -9470.48 & -5790.67 \\
\hline \multicolumn{6}{|l|}{ Colombia } \\
\hline Sectors making intensive use of technology & -419.61 & -1793.25 & -2205.66 & -6105.21 & -3876.11 \\
\hline Manufacturing sector as a whole & -677.89 & -2626.78 & -2810.82 & -8912.3 & -5403.23 \\
\hline
\end{tabular}

Source: The PADI computer programme.

TABLE 11

Latin America (five countries): Import coefficients

\begin{tabular}{|c|c|c|c|c|c|c|c|c|c|c|c|c|c|}
\hline \multirow[b]{2}{*}{ Sectors $^{a}$} & \multicolumn{5}{|c|}{ Argentina } & \multicolumn{4}{|c|}{ Brazil } & \multicolumn{4}{|c|}{ Mexico } \\
\hline & 1970 & 1980 & 1990 & 1998 & 1999 & 1970 & 1980 & 1990 & 1999 & 1970 & 1980 & 1990 & 1999 \\
\hline 0.1 & 28.3 & 33.3 & 21.4 & 126.0 & 112.8 & 22.9 & 13.6 & 10.1 & 36.6 & 26.1 & 32.3 & 42.9 & 105.5 \\
\hline 02 & 5.3 & 11.7 & 6.1 & 43.7 & 33.3 & 11.8 & 9.3 & 3.6 & 22.2 & 25.2 & 25.6 & 23.3 & 32.7 \\
\hline 03 & 17.8 & 23.5 & 14.8 & 77.0 & 65.5 & 19.0 & 12.3 & 8.0 & 31.6 & 25.8 & 29.8 & 34.2 & 72.7 \\
\hline 04 & 0.8 & 1.6 & 0.4 & 3.2 & 3.0 & 1.5 & 1.8 & 2.2 & 3.0 & 1.4 & 5.5 & 7.4 & 7.3 \\
\hline 05 & 23.9 & 14.9 & 10.6 & 28.8 & 27.0 & 12.3 & 9.6 & 5.5 & 14.3 & 10.7 & 19.0 & 17.5 & 52.9 \\
\hline 06 & 10.0 & 6.9 & 5.0 & 13.7 & 12.9 & 6.7 & 6.7 & 4.1 & 8.9 & 5.1 & 11.7 & 12.1 & 26.4 \\
\hline 07 & 3.8 & 7.5 & 4.0 & 26.4 & 27.4 & 2.2 & 1.7 & 2.1 & 9.2 & $4-0$ & 4.5 & 9.4 & 43.0 \\
\hline \multirow[t]{2}{*}{08} & 10.3 & 11.3 & 6.8 & 30.7 & 27.6 & 8.4 & 7.1 & 4.8 & 15.3 & $9-7$ & 15.1 & 17.8 & 49.4 \\
\hline & \multicolumn{5}{|c|}{ Chile } & \multicolumn{4}{|c|}{ Colombia } & & & & \\
\hline Sectors ${ }^{a}$ & 1970 & 1980 & 1990 & 1998 & 1999 & 1970 & 1980 & 1990 & 1998 & & & & \\
\hline 01 & 65.9 & 102.3 & 151.3 & 187.0 & 157.3 & 79.0 & 82.2 & 97.9 & 158.3 & & & & \\
\hline 02 & 47.5 & 133.4 & 151.7 & 211.0 & 142.6 & 112.4 & 64.1 & 44.2 & 98.7 & & & & \\
\hline 03 & 59.6 & 111.8 & 151.4 & 192.3 & 154.3 & 88.8 & 75.6 & 76.9 & 136.2 & & & & \\
\hline 04 & 6.7 & 10.4 & 3.8 & 7.2 & 6.7 & 2.5 & 4.7 & 2.5 & 8.8 & & & & \\
\hline 05 & 20.9 & 24.3 & 32.4 & 33.6 & 28.1 & 40.4 & 36.8 & 42.1 & 56.9 & & & & \\
\hline 06 & 12.9 & 15.7 & 15.4 & 18.1 & 15.4 & 15.5 & 16.4 & 18.6 & 27.5 & & & & \\
\hline 07 & 6.8 & 17.4 & 16.3 & 34.2 & 33.0 & 6.3 & 5.8 & 6.5 & 20.6 & & & & \\
\hline 08 & 21.0 & 30.1 & 34.3 & 44.0 & 35.8 & 22.9 & 22.4 & 24.0 & 42.4 & & & & \\
\hline
\end{tabular}

Source: The PADI computer programme.

a The corresponding sectors are:

01 Sectors making intensive use of engineering services, except the motor industry (ISIC 381, 382, 383, 385).

02 Motor industry (ISIC 384).

03 Total for sectors making intensive use of engineering services $(01+02)$.

04 Foodstuffs, beverages and tobacco (ISIC 311, 313, 314).

05 Other sectors making intensive use of natural resources (ISIC 331, 341, 351, 354, 355, 362, 369, 371, 372).

06 Total for sectors making intensive use of natural resources $(04+05)$.

07 Sectors making intensive use of labour (ISIC 321, 322, 323, 324, 332, 342, 352, 356, 361, 390).

08 Total for manufacturing. 
and Argentina went from surpluses to deficits, which grew up to 1997-1998. After the latter year the external sector shows improvements but this due to a drastic fall in the demand for imports (in Argentina, Chile and Colombia) and to devaluation of the local currency. In these four countries imports went down in 1999 compared with the previous year (the declines in nominal values were $19 \%$ for Argentina, 17\% for Brazil, 25\% for Chile and 28\% for Colombia), while exports also went down in nominal values in the case of Argentina, Brazil and Colombia and increased slightly in the case of Chile.

\section{IV}

\section{Conclusions}

The transition from an inward-oriented, State-led development model to another model which is more open to trade and deregulated -in which the "hidden hand" of markets plays a leading role in guiding resource allocation- has given rise in the different countries of the region to new patterns of production specialization and insertion in world markets for goods and services. This has taken place in the context of a Schumpeterian episode of "creative destruction" in which one model of social organization of production and institutional and technological behaviour was gradually displaced by another one, through the joint and interdependent action of economic, technological and institutional forces.

In previous pages we have shown that big changes have effectively been taking place in the pattern of production specialization and the form of insertion in world trade, so that two new "dominant" models have taken shape in the region as a whole. On the one hand, there is the "maquila" or assembly-based model, centered in Mexico and various small Central American countries, while on the other there is the model based on the processing of natural resources, which characterizes Argentina, Brazil, Chile and Uruguay, and various Andean countries such as Colombia and Peru.

Obviously, in order to understand the details of this process of change we must leave the macro sphere and descend to the mesoeconomic and microeconomic levels, since it is there that the changes in the dominant production organization model have taken place. There
In Mexico, the trade balance situation is different as a result of the strong increase in exports, which more than offset the also considerable rise in imports.

A more disaggregated analysis of the import coefficients (table 11) shows their impressive increase in the 1990s, which was concentrated primarily in the sectors producing capital goods and consumer durables (electronic goods, computer-related products and household appliances. The fall in domestic demand in the late 1990s reduced these coefficients in 1999 and thus lowered the trade deficit in Argentina, Chile, Colombia and Brazil. The improvement in Mexico's trade balance was due rather to an increase in that country's export capacity. have been changes in the relative participation of different types of firms - local subsidiaries of transnational groups, locally-owned conglomerates, and small and medium-sized family owned enterprises - as well as in the sources of economic growth of each type of production activity. New patterns of microeconomic behaviour have also been growing up in which imported capital goods and intermediate inputs have been displacing both their local production and the local technological efforts associated with their creation. A new production model has thus been taking shape which is more closely linked with the exterior than in the past.

Export-led growth does not seem to be as automatic as is sometimes assumed in the current debates, however. Our data clearly show that the process of growth and economic restructuring of the 1990s is raising a number of new and quite complex problems which, if not solved, can seriously compromise the growth prospects of the countries of the region.

It should be emphasized in this respect that not only were there very few countries in the region which have managed to improve their international competitiveness in the 1990s, but also this has only happened in a few production activities. These were mostly maquila industries making intensive use of unskilled labour and oriented basically to the United States market, or industries processing natural resources.

This is reflected in the weak relative performance labour productivity has exhibited as compared with the

SECTORAL REGIMES, PRODUCTIVITY AND INTERNATIONAL COMPETITIVENESS • JORGE KATZ AND GIOVANNI STUMPO 
United States: although almost all the countries registered a substantial increase in labour productivity in manufacturing in absolute terms in the 1990s, only in a very few cases (basically Argentina and Brazil) was that increase greater than in the United States and -what was worse- in no case did it recover the absolute levels of relative productivity of the early 1970s.

These weaknesses of the new economic model are clearly reflected in the trade deficits, which are mostly due to the technologically more complex activities. Moreover, these deficits tend to increase in the upswing of the cycle and tend to go down in periods of sharp recession.

The complexity of these problems leads to the conclusion that a great deal remains to be done in terms of economic policy. A number of countries of the region have begun to perceive this, and in recent years they have been abandoning strictly orthodox rules in order to begin exploring a new agenda of public actions through which to improve their long-term productivity and competitive performance.
On the basis of the above diagnosis, we suggest that important areas for future government involvement are: i) regulatory environments and consumer protection; ii) competition policies; iii) measures to promote production and technological development, and iv) interventions aiming at "constructing" synergies and externalities at the local levels. In each of these four spheres there are obvious "market failures", asymmetries of information, exploitation of dominant market positions by MNCs and other such "anomalies" that would justify the design and implementation of institutional measures aimed at constructing markets and knowledge-based dynamic comparative advantages that would favour a more efficient (and equitable) transition to open and competitive economies. Each of these topics would, of course, demand extensive analysis which is beyond the scope of this study to undertake.

(Original: Spanish)

\section{Bibliography}

Armstrong, M., S. Cowan and J. Vickers (1994): Regulatory Reform: Economic Analysis and the British Experience, Cambridge, Massachusetts, The MIT Press.

Azpiazu, D. and J. Basualdo (1997): La internacionalización reconsiderada: el caso de Siderar, Buenos Aires, July, mimeo.

Brown, F. (2000): La industria automotriz mexicana: reestructuración reciente y perspectivas, Santiago, Chile, Economic Commission for Latin America and the Caribbean (ECLAC), March, mimeo.

Buitelaar, R., R. Padilla and R. Urrutia (1999): Centroamérica, México y República Dominicana: maquila y transformación productiva. "Cuadernos de la CEPAL" series, No. 85, Santiago, Chile, ECLAC.

Caballero, R. and H. Hammour (1996): On the timing and efficiency of creative destruction, Quarterly Journal of Economics, vol. 111, No. 3, Cambridge, Massachusetts, The MIT Press.

Campos, R. and J. A..Nicolau (2000): Arranjo produtivo textilvestuario do vale do Itajais, nota técnica, Arranjos Produtivos Locais e as Novas Politicas de Desenvolvimento, Rio de Janeiro, mimeo.

Cassiolato, J. and H. Lastres (2000a): Local systems of innovation in Mercosur countries, Industry and Innovation, vol. 7, No. 1, reproduced in Arranjos Produtivos Locais e as Novas Politicas de Desenvolvimento, Rio de Janeiro, mimeo.

(2000b): Novas politicas industriais descentralizadas em paises seleccionados, in Institute of Applied Economic Research (IPEA), Relatorio de pesquisa, Rio de Janeiro (IE)/ Federal University of Rio de Janeiro, mimeo.

Cimoli, M. and J. Katz (2001): Reformas estructurales, brechas tecnológicas y el pensamiento del Dr. Prebisch. This document was presented at the international seminar "La teoría del desarrollo en los albores del siglo XXI", held in commemoration of the centenary of the birth of Raúl Prebisch (EClac, Santiago, Chile, 28-29 August 2001.

Confederação Nacional da Indústria (1997): Políticas estaduais de apoio a industria, Rio Grande do Sul, Brazil, Secretaria da Coordenação e Planejamento.

David, P. (1994): Why are institutions the "carriers of history". Path dependence and the evolution of conventions, organizations and institutions, Structural Change and Economic Dynamic, vol. 5, No. 2.

Dussel P. E. (2000a): Polarizing Mexico: the impact of liberalization strategy, London, Lynne Riener.

(2000b): El programa de promoción sectorial (Prosec). Implicaciones para las importaciones temporales y el resto del aparato productivo mexicano, October, mimeo.

ECLAC (2000): Equity, Development and Citizenship, LC/ G.2071(SES.28/3), Santiago, Chile.

Fernández Arias, E., R. Hausmann and E. Stein (2001): Courting FDI: is competition bad?, Santiago, Chile, January, mimeo.

Ffrench-Davis, R. (1999): Entre el neoliberalismo y el crecimiento con equidad: Tres décadas de política económica en Chile, Santiago, Chile, Dolmen Ediciones.

Garrido, C. (2000): Fusiones y adquisiciones transfronterizas en México durante los noventa, Mexico City, Autonomous Metropolitan University (UAM).

Gerber, J. (2000): Uncertainty and growth in the maquiladora industry, San Diego, San Diego State University, Department of Economics, mimeo.

Goldstein, A. (2000): From national champion to global player: explaining the success of Embraer, Paris, Organization for Economic Cooperation and Development (OECD), mimeo. 
Gordon, R. (1999): Has the new economy rendered the productivity slowdown obsolete?, Cambridge, Massachusetts, National Bureau of Economic Research (NBER), June.

Held, G. (1999): Políticas de crédito para empresas de menor tamaño con bancos de segundo piso: experiencias recientes en Chile, Colombia y Costa Rica, "Financiamiento del desarrollo" series, No. 84, Santiago, Chile, EClaC.

Katz, J. (1974): Oligopolio, firmas nacionales y empresas multinacionales. La industria farmacéutica argentina, Buenos Aires, Siglo XXI.

(1996): Apertura y desregulación en el mercado de medicamentos, Buenos Aires, ECLAC/International Development Research Centre (IDRC)/Alianza Editorial,

(1997): Aprendizaje y desarrollo de capacidades tecnológicas domésticas en la etapa de la sustitución de importaciones, Buenos Aires, Pulso/Socma.

(1998): Pulso, Buenos Aires.

(2000): Reformas estructurales, productividad y conducta tecnológica en América Latina, Santiago, Chile, ECLAC/Fondo de Cultura Económica.

Kulfas, M. (2000): El impacto del proceso de fusiones y adquisiciones en la Argentina sobre el mapa de las grandes empresas. Factores determinantes y transformaciones en el universo de las grandes empresas de capital local, Buenos Aires, ECLAC Office in Buenos Aires.

Miranda, J. C. (2000): Abertura comercial, reestruturação industrial e exportações brasileiras. Avaliação de potencial exportador das 500 maiores empresas industrias brasileiras, Proyecto CLA/99-1671, Rio de Janeiro, Universidade Geral de Rio de Janeiro, September.

Moguillansky, G. and R. Bielschowsky (2000): Inversión y reformas económicas en América Latina, Santiago, Chile, Fondo de Cultura Económica/ECLAC.

Mortimore, M., and W. Peres (2001): La competitividad internacional de América Latina y el Caribe. Las dinámicas microeconómicas y sectoriales, Santiago, Chile, ECLAC, mimeo.

Naim, M. and J. S. Tulchin (1999): Competition policy, deregulation and modernization in Latin America, London, Lynne Riener.

Nelson, Richard. (1997): How new is new growth theory?, New York, Challenge.

Nelson, Roy (undated): Intel site selection decision in Latin America, Glendale, Arizona, Thunderbird University, Department of International Studies, mimeo.
Ocampo, J. A. (2001): Rethinking the Development Agenda, Santiago, Chile, EClaC.

Olson, M. (1991): Political influence and the development of US regulatory policy: The 1984 drug legislation, CEPR discussion paper, No. 249, Stanford, California, Center for Economic Policy Research (CEPR).

Patel, S. J., P. Roffe and A. Yusuf (2001): International Technology Transfer, London, Kluwer Law International.

Peres, W. and G. Stumpo (2000): Small and medium-sized industrial enterprises in Latin America and the Caribbean under the new economic model, World Development, vol. 28, No. 9, Oxford, U.K., Pergamon Press Ltd., September.

Projeto de Pesquisa Arranjos Produtivos Locais (2000): No. 18, Rio de Janeiro, September, mimeo.

Roffe, P. and T. Tesfachew (2001): The unfinished agenda, in S. J. Patel, P. Roffe and A. Yusuf, International Technology Transfer, London, Kluwer Law International.

Rubens, J., N. Cano and A. L. Gonçalves da Silva (2000): Arranjo Produtivo de Telecomunicações de Campinas, nota técnica, No. 16, Rio de Janeiro, Projeto de Pesquisa Arranjos e Sistemas Produtivos Locais, September, mimeo.

Schmitz, H. (1995): Small shoemakers and Fordist giants: tale of a supercluster, World Development, vol. 23, No. 1, Oxford, U.K., Pergamon Press Ltd.

Sercovich, F. (1999): Competition and the World Economy, Cheltenham, U.K., Edward Elgar/United Nations Industrial Development Organization (UNIDO).

Stallings, B. and W. Peres (2000): Growth, Employment and Equity: The Impact of the Economic Reforms in Latin America and the Caribbean, New York, ECLAC/Brookings Institution Press.

Tavares de Araujo, J. (2000): Competition policy and EU-Mercosur trade negotiations, mimeo.

Vargas, M. A. and R. M. Alievi (2000): Arranjo produtivo coureirocalcadista do vale dos Sinos, nota técnica, No. 19, Rio de Janeiro, Projeto de Pesquisa Arranjos e Sistemas Produtivos Locais, September, mimeo.

Weller, J. (2000): Reformas económicas, crecimiento y empleo: los mercados de trabajo en América Latina y el Caribe, Santiago, Chile, ECLAC/Fondo de Cultura Económica.

World Development (2000): vol. 28, No. 9, Oxford, U.K., Pergamon Press Ltd. 